Research Article

\title{
Oxidative Stress and Apoptosis Contributed to Nonylphenol-Induced Cell Damage in Mouse NCTC Clone 1469 Cells
}

\author{
Xiaozhen Liu, ${ }^{1,2,3}$ Yangjie Chen, ${ }^{1}$ Shaoping Nie, ${ }^{1}$ Fuxiang Li, ${ }^{3}$ Zhaoliang Zhu, ${ }^{3}$ Gaoyi Peng, \\ Qiang Yu, ${ }^{1}$ and Mingyong Xie $\mathbb{1}^{1}$ \\ ${ }^{1}$ State Key Laboratory of Food Science and Technology, Nanchang University, Nanchang 330047, China \\ ${ }^{2}$ School of Chemical Engineering and Energy Technology, Dongguan University of Technology, Dongguan 523808, China \\ ${ }^{3}$ Engineering Research Center of Health Food Design \& Nutrition Regulation, Institute of Science \& Technology Innovation, \\ Dongguan University of Technology, Dongguan 523808, China
}

Correspondence should be addressed to Mingyong Xie; myxie@ncu.edu.cn

Received 19 June 2020; Revised 18 August 2020; Accepted 14 September 2020; Published 26 September 2020

Academic Editor: Maolin Guo

Copyright (C) 2020 Xiaozhen Liu et al. This is an open access article distributed under the Creative Commons Attribution License, which permits unrestricted use, distribution, and reproduction in any medium, provided the original work is properly cited.

Nonylphenol (NP) is considered an environmental toxicant and endocrine-disrupting compound. The present study aimed to investigate the effects of NP on NCTC Clone 1469, nonparenchymal hepatocytes, and to study the molecular basis of NP-induced liver injury. The results showed that NP decreased cell viability and induced nucleus crenulation and intracellular enzyme leakage in NCTC Clone 1469 cells. Additionally, NP-induced oxidative stress and apoptosis of NCTC Clone 1469 are accompanied by upregulating reactive oxygen species (ROS) production, increase of Bax, decrease of Bcl-2, activation of caspase-3 and caspase-12, and release of cytosolic free $\mathrm{Ca}^{2+}$ in the cells. ROS scavenger, N-acetyl-L-cysteine (NAC), prevented the intracellular enzyme leakage induced by NP. NP induced alteration of estrogen receptor- (ER-) $\alpha$ and ER- $\beta$ expression, while ER antagonists, ICI 182,780 , showed no effect on NP-induced intracellular enzyme leakage. We proposed that NP triggered cell damage via inducing oxidative stress and apoptosis in cells, but not estrogenic effect.

\section{Introduction}

Nonylphenol polyethoxylate (NPEO) is a kind of alkylphenol polyethoxylates, which are widely used as emulsifiers, plasticizers, and detergents [1]. Nonylphenol (NP), one of the degraded products of NPEOs, has also been used extensively in cleaners, cosmetics, pesticides, plastics, surfaceactive agents, polyvinyl chloride pipes, food processing and packaging industry, and other industrial and agriculturally formulated products [2-6]. NP has been detected in most of the retailed food, and it may be widespread in our daily food. Studies have shown that NP could be absorbed by aquatic wildlife species, especially by fish, and then accumulated in the human body through the food chain $[7,8]$. In addition, $\mathrm{NP}$ can also migrate from food packaging films to food simulants during the process of cooking and microwaving
$[9,10]$. Due to the bioaccumulative characteristic of NP, it can be harmful to the biological systems in a very low concentration.

Researches have indicated that the chemical structure of NP resembled the estrogenic hormone in animal and human and can cause the endocrine disorder [11]. Not only can NP disrupt endocrine but also it has toxic effects on systemic organs of the human body [12-14]. Several studies have shown that the gestational exposure of NP could damage the reproductive, neural, and digestive systems in rats [15]. The liver is an important immune organ and is the site of biological transformation and metabolism of exogenous chemicals. It is also the main target of chemicals for biological and chemical injury. NP administered by oral gavage was reported to be distributed to all tissues, and there was a higher distribution in the liver than other tissues [16]. 
However, until recently, most research has focused on the adverse effects of NP on the reproductive system, and little has been known regarding the effects of NP on liver injure. Consequently, this study was proposed to investigate the underlying mechanisms of NP toxicity on liver cells.

Apoptosis is a process of programmed cell death, which may happen in multicellular organisms [17]. In recent years, more and more researchers have been concerned about apoptosis induced by environmental pollutants. There have been a great number of reports suggesting that apoptosis is one of the most important reasons that cause the toxicity induced by environmental endocrine disruptors $[18,19]$. It was reported that NP enhanced apoptosis in sperm cells, thymocyte cells, Sertoli cells, and human embryonic stem cells [20-22]. We previously showed that NP induced oxidative stress and apoptosis in TM4 cells, and the apoptosis may be mediated via MAPKs and Akt pathways [23]. Although many studies have provided evidence for NP-induced cell death, the detailed mechanisms or pathways of liver cell death remain unclear. Therefore, in this study, we assessed the toxicity of NP in a mice liver cell line, NCTC Clone 1469, with the specific aim of studying the role of oxidative damage and apoptosis in hepatotoxicity.

\section{Materials and Methods}

2.1. Reagents and Chemicals. NP (99.9\% purity, CAS: 10440-5), penicillin, streptomycin sulfate, and 5(6)-carboxy- $2^{\prime}$ $7^{\prime}$-dichlorofluorescein diacetate (DCFH-DA) were purchased from Sigma-Aldrich Inc., (St. Louis, MO, USA). Dulbecco's modified Eagle's medium-high glucose medium (DMEM-H medium) and fetal bovine serum (FBS) were obtained from Hyclone (Waltham, MA, USA). Fulo-3/AM was purchased from Beyotime Institute of Biotechnology (Haimen, Jiangsu, China). Annexin V/PI apoptosis assay kit was purchased from Invitrogen Co. (Eugene, Oregon, USA). Antibodies against Bax, Bcl-2, ER- $\alpha$, and ER- $\beta$ were obtained from Santa Cruz Biotechnology, Inc. (CA, USA). Caspase-3 and caspase-12 activity assay kits were purchased from BioVision (Research, Mountain View, California). z-ATADfmk and z-DEVD-fmk were purchased from Becton Dickinson Company (Palo Alto, CA, USA). All other chemicals were analytical agents.

Nonparenchymal hepatocytes, NCTC Clone 1469 cells, were obtained from American Type Culture Collection (ATCC, Rockville, MD). Cells were maintained in DMEM-H medium, supplemented with $1 \%$ penicillin-streptomycin, $10 \%(\mathrm{v} / \mathrm{v})$ FBS in an atmosphere with $95 \%$ humidity and $5 \% \mathrm{CO}_{2}$ at $37^{\circ} \mathrm{C}$.

2.2. Cell Cytotoxicity Assay. Cell viability was detected by $3-$ [4, 5-dimethylthiazol-2yl]-2, 5-diphenyl tetrazolium bromide (MTT) test. Briefly, cells were plated on a 96-well culture plate at $2 \times 10^{4}$ cells/well in $100 \mu \mathrm{L}$ culture medium. Cells were treated with NP, followed by the addition of $25 \mu \mathrm{L}$ MTT solution $(5 \mathrm{mg} / \mathrm{mL})$ to each well and further incubation for $4 \mathrm{~h}$ at $37^{\circ} \mathrm{C}$. The supernatants were removed before adding $150 \mu \mathrm{L}$ DMSO to dissolve the formazan crystal. The absorbance was measured on an automated microplate reader (Varioskan Flash, Thermo Scientific, USA) at $570 \mathrm{~nm}$. Cell viability in each test group was expressed as a percentage of the control group. Cells in the control group were as $100 \%$ viable. In addition, after treatment with $60 \mu \mathrm{M} N$ for $12 \mathrm{~h}$, cells were observed by microscopy.

2.3. Leakage of $L D H, A L T$, and AST. Cells were challenged with NP at different concentrations $(0,1,10,20,40$, or $60 \mu \mathrm{M})$ for $12 \mathrm{~h}$ and then the supernatant was collected for further analyses. LDH, ALT, and AST leakages were quantified according to the manufacturer's instructions of commercial enzymatic kits (Jiancheng Bioengineering Institute, Nanjing, China), respectively.

2.4. Determination of Intracellular ROS Production. NP-treated NCTC 1469 cells were collected and washed with cold phosphate-buffered saline (PBS). Washed cells were further incubated with $10 \mu \mathrm{M}$ DCFH-DA at $37^{\circ} \mathrm{C}$ for $20 \mathrm{~min}$. Then, cells were washed with PBS and measured using a flow cytometer with excitation and emission settings of 488 and $530 \mathrm{~nm}$, respectively.

2.5. Measurement of Malondialdehyde (MDA) Content and Enzyme Activities. To detect the intracellular MDA content and antioxidant enzyme activities, the NP-treated cells were washed twice with PBS, then harvested from the plates into ice-cold PBS (0.1 M, containing 0.05 mM EDTA), and homogenized. The homogenate was centrifuged at $4^{\circ} \mathrm{C}$ at $12,000 \mathrm{~g}$ for $30 \mathrm{~min}$. The resulting supernatant was used for the measurement of MDA content, superoxide dismutase (SOD) activity, and catalase (CAT) activity according to the instructions for the kits (Jiancheng Bioengineering Institute, Nanjing, China). Protein concentration was determined by the Bradford method, using bovine serum albumin as a reference standard.

\subsection{Detection of Cytosolic-Free Calcium Levels.} NP-treated cells were collected, loaded with $5 \mu \mathrm{M}$ of Fulo-3/ $\mathrm{AM}$ for $30 \mathrm{~min}$ in the dark at $37^{\circ} \mathrm{C}$, and then washed to remove extracellular Fluo-3/AM dye. Then, $\left[\mathrm{Ca}^{2+}\right] \mathrm{i}$ in the cells were measured by using a flow cytometer.

2.7. Apoptosis Analysis with Annexin V-FITC and PI Staining. Cells at the density of $1 \times 10^{6}$ cells/well were incubated in the presence of NP for $12 \mathrm{~h}$ and then harvested. Specific binding of Annexin V-FITC was carried out by incubating the cells for $15 \mathrm{~min}$ at room temperature in binding buffer $(10 \mathrm{mM}$ HEPES, $140 \mathrm{mM} \mathrm{NaCl}, 2.5 \mathrm{mM} \mathrm{CaCl}_{2}, \mathrm{pH}$ 7.4) containing a saturating concentration of Annexin V-FITC and PI, and then apoptosis was measured by a flow cytometer.

2.8. Expression Analysis of Bax and Bcl-2. The protein content was determined by using BCA protein assay kit (Beyotime, Jiangsu, China). Cell lysates were denatured by boiling in loading buffer $(20 \mathrm{mM}$ Tris- $\mathrm{HCl}, \mathrm{pH} 6.8,10 \%$ glycerol, $4 \%$ SDS, $100 \mathrm{mM}$ DTT, and $0.04 \%$ bromophenol 
blue). Samples (approximately $40 \mu \mathrm{g}$ protein) were loaded onto $10 \%$ SDS polyacrylamide gel followed by electroblotting onto a nitrocellulose membrane. After blocking of nonspecific binding with $5 \%$ bovine serum albumin (prepared in TBS containing $0.1 \%$ Tween 20 ) for $2 \mathrm{~h}$ at room temperature, the membranes were then incubated with 1 : 1000 diluted antibodies against $\mathrm{Bcl}-2, \mathrm{Bax}$, and $\beta$-actin and washed 3 times in TBS-T. The membranes were incubated with appropriate HRP-labeled goat anti-mouse or goat antirabbit secondary antibody IgG for $2 \mathrm{~h}$ at room temperature and washed 3 times in TBS-T; then, the protein was detected using enhanced chemiluminescence (ECL). Densitometry was performed using the software Quantity One.

Bcl-2 and Bax mRNA expression levels were analyzed by reverse transcription-polymerase chain reaction (RT-PCR). Total RNA was extracted using Trizol Reagent (Invitrogen, Carlsbad, CA, USA) according to the manufacturer's instructions. The cDNA was reverse transcribed from the RNA using First Strand cDNA Synthesis Kit (Thermo Scientific, Maryland, USA) and then was amplified based on the first cDNA template through polymerase chain reaction. The sequences of primers used for RT-PCR are shown in Table 1. PCR conditions were used as follows: $94^{\circ} \mathrm{C}$ for $3 \mathrm{~min}$, followed by 29 cycles of denaturation at $94^{\circ} \mathrm{C}$ for $30 \mathrm{~s}$, annealing at $60^{\circ} \mathrm{C}\left(\beta\right.$-actin), $54^{\circ} \mathrm{C}(\mathrm{Bcl}-2)$, or $60^{\circ} \mathrm{C}(\mathrm{Bax})$ for $30 \mathrm{~s}$, and extension at $72^{\circ} \mathrm{C}$ for $2 \mathrm{~min}$, plus final extension at $72^{\circ} \mathrm{C}$ for $10 \mathrm{~min}$. PCR products were analyzed by GoldView-agarose gel electrophoresis on $2 \%(\mathrm{w} / \mathrm{v})$ agarose gel and visualised under UV light. The signals of Bcl-2 and Bax were measured by scanning densitometry using Quantity One software.

2.9. Caspase-3 and Caspase-12 Activities Assay. To investigate the mechanism of NP-induced apoptosis in NCTC 1469 cells, activities of caspase- 3 and caspase- 12 were detected in the present study. The assays were performed on 96-well microplates through incubating $10 \mu \mathrm{L}$ protein of cell lysate in $80 \mu \mathrm{L}$ reaction buffer $(1 \% \mathrm{NP}-40,20 \mathrm{mM}$ Tris $-\mathrm{HCl}, 137 \mathrm{mM}$ $\mathrm{NaCl}$, and $10 \%$ glycerol, $\mathrm{pH}$ 7.5) containing $10 \mu \mathrm{L}$ caspase- 3 (Ac-DEVD-pNA) or caspase-12 (Ac-ATAD-pNA) substrate $(2 \mathrm{mM})$. Lysates were incubated at $37^{\circ} \mathrm{C}$ for $4 \mathrm{~h}$, and then samples were measured on an automated microplate reader with a $400 \mathrm{~nm}$ excitation and $505 \mathrm{~nm}$ emission. Caspase-3 inhibitor, z-DEVD-fmk, or caspase-12 inhibitor, ATAD-fmk, was also used to confirm whether NP-induced apoptosis was mediated by caspase activation. Inhibitors were added to the cell cultures half an hour before the NP treatment.

2.10. Analysis of Estrogen Receptors Expression. Protein expression of ER- $\alpha$ and ER- $\beta$ was detected by western blot, mRNA expression levels of ER- $\alpha$ and ER- $\beta$ were examined by RT-PCR, assays were performed as 2.9 described, and the annealing temperature for both ER- $\alpha$ and ER- $\beta$ was $60^{\circ} \mathrm{C}$.

ICI 182,780 , a nonsteroidal selective estrogen receptor modulator, can compete with endogenous estrogens for receptor binding. In the current study, $100 \mu \mathrm{M}$ of ICI 182,780 (Fulvestrant, Sigma) was used to confirm whether the estrogenic effect was involved in NP-mediated liver cell injury. After the NCTC Clone 1469 were cultured for $24 \mathrm{~h}$, the reagents were added into the medium half an hour before the NP treatment. After $12 \mathrm{~h}$ of NP treatment, NCTC Clone 1469 were collected and used for assays.

2.11. Statistical Analysis. Results were expressed as mean \pm S.D. One-way analysis of variance followed by the LSD test was used to determine the statistical significance between various groups (ANOVA) in SPSS (Windows version 11.9), and a value of $P<0.05$ was accepted to be statistically significant.

\section{Results}

3.1. Cytotoxicity of NP. To evaluate the cytotoxicity of NP on NCTC Clone 1469, time course and dose response of cell viability were tested using the MTT method. As shown in Figure 1(a), no significant difference was observed in the $1-40 \mu \mathrm{M}$ NP groups, compared with the control group. However, cell viability significantly decreased in $60 \mu \mathrm{M}$ $(70.28 \pm 5.24 \%), \quad 80 \mu \mathrm{M} \quad(63.84 \pm 4.09 \%), \quad$ and $100 \mu \mathrm{M}$ $(50.46 \pm 6.18 \%) \mathrm{NP}$ treatment groups. Additionally, the results showed that cell viability decreased in a time-dependent manner, and $0.1 \%$ DMSO showed no effects on cell viability. Besides, it was found that NCTC Clone 1469 presented nucleus crenulation after NP treatment, with being more and more serious over time (Figure 1(b)), suggesting that NP exerted damage effect to NCTC Clone 1469.

LDH, ALT, and AST are important intracellular enzymes, which are indicators of liver cell damage [24, 25]. After NCTC Clone 1469 was cultured with various concentrations of NP for $12 \mathrm{~h}$, the activities of LDH, ALT, and AST in high NP treatment groups were increased compared with the control group. As shown in Figure 1(c), LDH activity significantly increased in high concentrations of $20 \mu \mathrm{M}(P<0.05)$ and 40 and $60 \mu \mathrm{M}(P<0.01)$ NP groups, ALT activity significantly increased in 40 and $60 \mu \mathrm{M}$ NPtreated groups $(P<0.05)$, and AST activity significantly increased in $60 \mu \mathrm{M}$ NP-treated group $(P<0.05)$.

3.2. NP-induced Oxidative Stress in NCTC Clone 1469. ROS generation and lipid peroxidation were indicators of oxidative stress. Recently, more and more studies have demonstrated that a balance between ROS production and antioxidants system was associated with cell death [26]. Thus, ROS generation, antioxidant enzyme activities, and MDA content were detected in the present study. Intracellular ROS was increased in a dose-dependent manner in NP challenged NCTC Clone 1469, which was statistically significant in $40-60 \mu \mathrm{M}$ NP groups with $P<0.01$ (Figure 2(a)), and antioxidant $\mathrm{N}$-acetyl-L-cysteine (NAC) attenuated NP-induced ROS production (Figures 2(a)G). As shown in Figure 2(b), SOD activities in 40-60 $\mu \mathrm{M}$ NP groups significantly decreased compared with the control group $(P<0.01)$, and CAT activities significantly decreased in $20 \mu \mathrm{M}$ $(P<0.01)$ and $40 \mu \mathrm{M}$ and $60 \mu \mathrm{M}(P<0.01) \mathrm{NP}$ groups. In contrast, MDA levels increased in $40 \mu \mathrm{M}$ or $60 \mu \mathrm{M}$ NP-treated NCTC Clone 1469 with $P<0.01$. Moreover, NAC treatment prevented the decrease of SOD and CAT activities and the increase of MDA contents in $60 \mu \mathrm{M}$ NP treatment group 
TABLE 1: Sequences of primers used for RT-PCR.

\begin{tabular}{|c|c|c|}
\hline Gene name & Sequence $\left(5^{\prime}-3^{\prime}\right.$ direction $)$ & Product size (bps) \\
\hline ER- $\alpha$ & $\begin{array}{l}5^{\prime} \text {-GGCCTGACTCTGCAGCAGCAG-3'(F) } \\
5^{\prime} \text {-GTTGGGGAAGCCCTCTGCTTC-3'(R) }\end{array}$ & 300 \\
\hline ER- $\beta$ & $\begin{array}{l}5^{\prime} \text {-GGCATTCTACAGTCCTGCTG-3'(F) } \\
5^{\prime} \text {-TCTGCATAGAGAAGCGATGA-3'(R) }\end{array}$ & 165 \\
\hline Bcl-2 & $\begin{array}{c}5^{\prime} \text {-CGCCGGGCTGGGGATGACTTC-3'(F) } \\
5^{\prime} \text {-CACTTGTGGCCCAGGTATGC-3 }(\mathrm{R})\end{array}$ & 428 \\
\hline Bax & $\begin{array}{c}5^{\prime} \text {-CTCCAACOAGGAAAATGATA-3 }{ }^{\prime}(\mathrm{F}) \\
5^{\prime} \text {-TCATGGAACTGATGATGATGAA-3 }(\mathrm{R})\end{array}$ & 250 \\
\hline$\beta$-Actin & $\begin{array}{l}5^{\prime} \text {-ATTGTAACCAACTGGGACG-3'(F) } \\
5^{\prime} \text {-TTGCCGATAGTGATGACCT-3'(R) }\end{array}$ & 533 \\
\hline
\end{tabular}

(Figure 2(c)). These results implied that NP could significantly induce lipid peroxidation and oxidative stress in NCTC Clone 1469 cells, which may result in liver damage in final.

3.3. NP-Induced Apoptosis in NCTC Clone 1469. NP-induced apoptosis in NCTC Clone 1469 was analyzed by flow cytometry. After treatment with NP at various concentrations for $12 \mathrm{~h}$, the proportion of apoptotic cells increased in a dose-dependent manner (from $3.21 \pm 1.66 \%$ to $24.66 \pm 2.51 \%$ ). The data showed that there was no significant difference in the percentage of apoptotic cells between the control group and the low concentration of NP treatment groups (1 and $10 \mu \mathrm{M})$. However, the percentage of apoptotic cells increased dramatically by the treatment with NP at 20, 40 , or $60 \mu \mathrm{M}$ $(P<0.01)$. Caspases cascade played a central role in regulating various apoptotic responses [27]. DEVD-fmk or ATAD-fmk, caspase-3 or caspase-12 inhibitor, was used to substantiate whether caspases activation was involved in NP-induced apoptosis. The results showed that DEVD-fmk and ATAD-fmk significantly downregulated the proportion of apoptotic cells induced by $60 \mu \mathrm{M}$ NP $(P<0.01$, Figure 3$)$.

The activities of caspase- 3 and caspase-12 in NCTC Clone 1469 with or without NP treatment were examined. As shown in Figure 4, treatment of liver cells with NP caused remarkable activation of caspase-3 in $20-60 \mu \mathrm{M}$ NP groups, and activation of caspase-12 in $10-60 \mu \mathrm{M}$ NP groups.

Moreover, stress/toxicant-mediated apoptosis is also mediated by Bcl- 2 family proteins $[28,29]$. Thus, the mRNA and protein expression levels of Bcl-2 and Bax were determined in this study. NP significantly increased the mRNA level of Bax at $40-60 \mu \mathrm{M}(P<0.01)$. In contrast, NP decreased the mRNA level of Bcl-2 in a dose-dependent manner, which was statistically significant in $20(P<0.05)$, 40 , and $60 \mu \mathrm{M}(P<0.01) \mathrm{NP}$ treatment groups (Figures 5(a) and 5(b)). Consistent with the mRNA expression, NP increased the protein expression of Bax and decreased that of Bcl-2 in 20-60 $\mu \mathrm{M}$ NP groups (Figures 5(c) and 5(d)).

3.4. Intracellular $\mathrm{Ca}^{2+}$ Level. $\left[\mathrm{Ca}^{2+}\right] \mathrm{i}$ change in NP treatment cells was analyzed by using flow cytometry with Fluo-3/AM. As shown in Figure 6, compared with the control group, $\left[\mathrm{Ca}^{2+}\right] \mathrm{i}$ fluorescence intensity was increased in a dose-dependent manner in the groups treated with NP (from $4.35 \%$ to $36.41 \%$ ) and showed a significant statistic difference in $40-60 \mu \mathrm{M}$ $(P<0.01)$. While pretreatment with caspase- 3 or caspase-12 inhibitor, DEVD-fmk or ATAD-fmk, intracellular $\left[\mathrm{Ca}^{2+}\right] \mathrm{i}$ overload reduced when compared with $60 \mu \mathrm{M}$ NP group, which suggested that apoptosis resulted in $\left[\mathrm{Ca}^{2+}\right] \mathrm{i}$ overload in the cells and the alteration of $\left[\mathrm{Ca}^{2+}\right] \mathrm{i}$ may source from $\mathrm{Ca}^{2+}$ influx or endoplasmic reticulum $\mathrm{Ca}^{2+}$ release.

3.5. Protein and mRNA Expression of Estrogen Receptors. $\mathrm{NP}$, considered as an environmental endocrine disruptor, acts by competing with hormone receptors [30]. In order to make it clear whether the estrogenic effect was involving NP-induced oxidative stress and apoptosis in nonparenchymal hepatocytes, RT-PCR and western blotting were performed to analyze the expression of ER- $\alpha$ and ER- $\beta$ in NCTC Clone 1469. Compared with the control group, NP treatment significantly increased the mRNA expression of ER- $\alpha$ and ER- $\beta$, which were statistically significant at $10-60 \mu \mathrm{M}(P<0.01)$ and $1-40 \mu \mathrm{M}(P<0.05) \mathrm{NP}$ groups, respectively. Interestingly, the mRNA expression of ER- $\beta$ decreased at $60 \mu \mathrm{M}$ NP treatment group (Figures $7(\mathrm{a})$ and $7(\mathrm{~b})$ ), which implied that NP may exert damage toxicity to NCTC Clone 1469 in high concentration. Meanwhile, the protein expression of ER- $\alpha$ increased remarkably in $40-60 \mu \mathrm{M}(P<0.01)$, that of ER- $\beta$ was distinctly increased in $10-20 \mu \mathrm{M}(P<0.01)$ and $40 \mu \mathrm{M}$ $(P<0.05)$ NP groups, and the protein expression of ER- $\beta$ decreased in $60 \mu \mathrm{M}$ NP group as well (Figures $7(\mathrm{c})$ and $7(\mathrm{~d})$ ). These interesting findings implied that NP may influence the expression ER- $\alpha$ and ER- $\beta$ in NCTC Clone 1469.

3.6. Effects of NAC and ICI 182,780 on NP-Induced Cell Damage. To confirm whether NP exerted cytotoxicity by inducing oxidative stress and apoptosis in the cells, the ROS scavenger and NAC, were used to investigate the putative role of ROS in LDH, ALT, and AST upregulation in our experimental model. In our experimental model, the ROS scavenger, NAC, was used to investigate the putative role of NP stimulated ROS in $\mathrm{LDH}, \mathrm{ALT}$, and AST upregulation induced by NP. The release of LDH, ALT, or AST in NAC pretreatment group was remarkably inhibited when compared with $60 \mu \mathrm{M}$ NP-treated group (Figure 8), suggesting that oxidative stress potentially contributed to NP-induced cell damage. However, there was no significant difference between ICI pretreated group and $60 \mu \mathrm{M}$ NP exposure group in LDH, ALT, and AST activities (Figure 8), which indicated that toxic effects of NP on the liver cells may be not related to its estrogenic effect. 


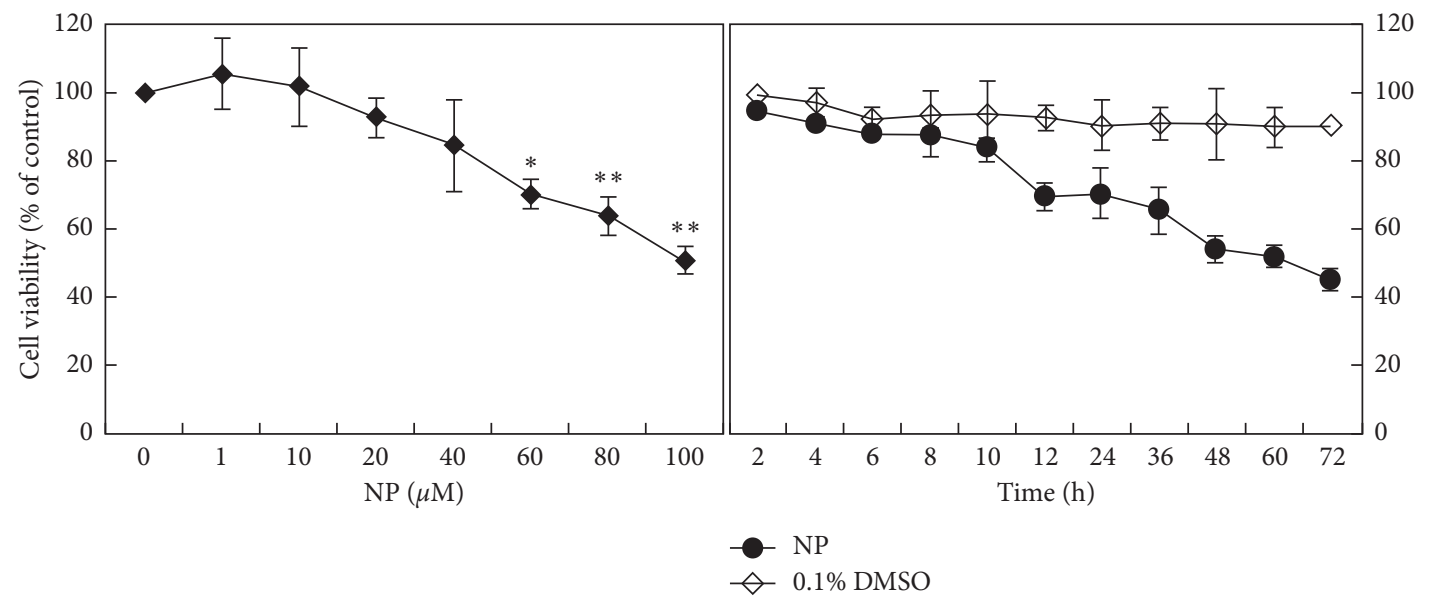

(a)
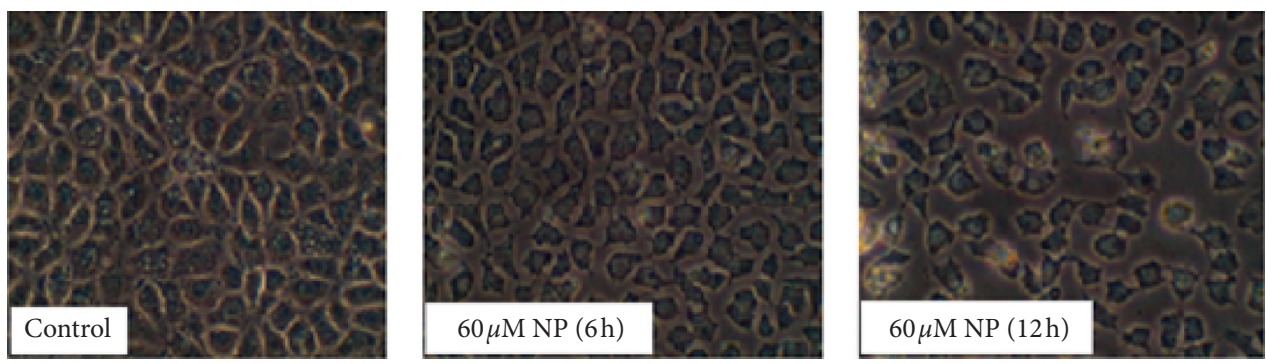

(b)

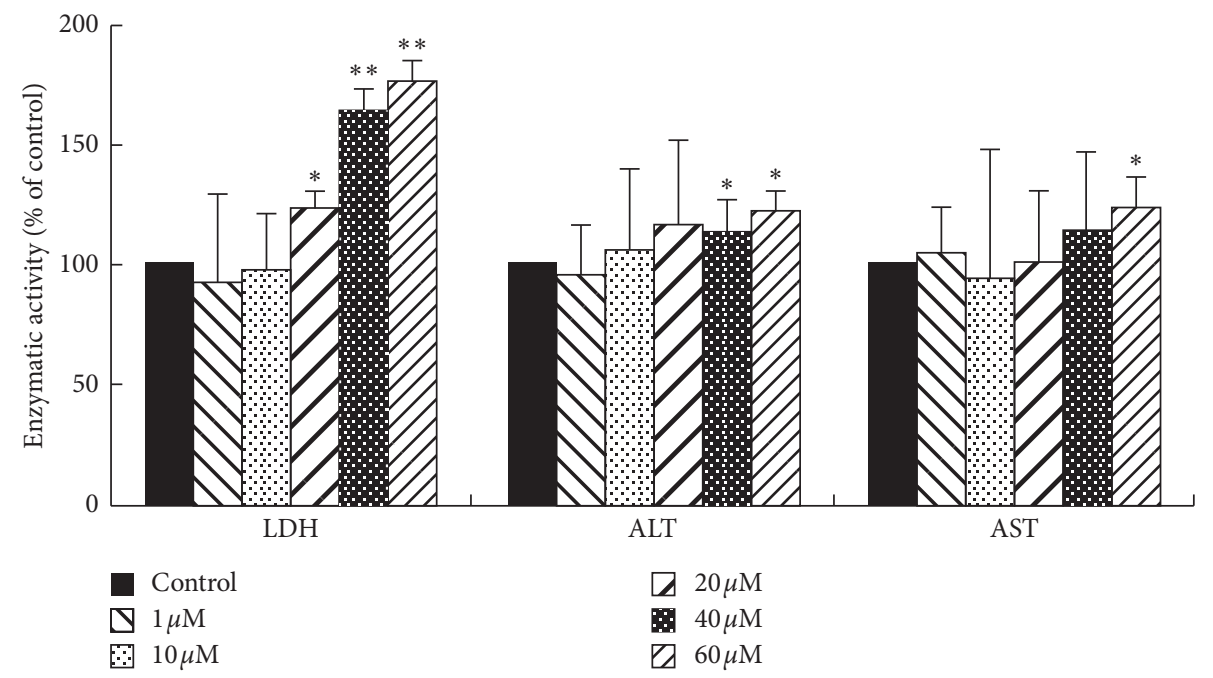

(c)

Figure 1: NP induced cytotoxicity to NCTC Clone 1469 cells. (a) Time- and dose-dependent cell viability. Cultured cells were exposed to different concentrations of NP $(0,1,10,20,40,60$, and $100 \mu \mathrm{M})$ for $12 \mathrm{~h}$ or $60 \mu \mathrm{M}$ NP for different time periods $(2,4,6,8,10,12,24,36,48$, 60 , and $72 \mathrm{~h}$ ). After the experiment, cell viability was examined by MTT assay. (b) Cell morphology was examined by microscopy with a photography system. (c) Effect of NP on LDH, ALT, and AST leakage in the supernatant. The activities of the LDH, AST, and ALT were expressed as $\%$ of control. Results are presented as mean $\pm \mathrm{SD}$ with triplicate measurement. ${ }^{*} P<0.05,{ }^{* *} P<0.01$ versus the control group.

\section{Discussion}

The potential hazard of NP to human health has attracted many researchers' attention. NP, a typical representative of endocrine disruptors, may cause damage to the body's endocrine system. However, when assessing the harm of NP to the body, we should consider its overall damage. Studies have shown that maternal exposure to NP can cause liver tissue lesions in rats [31]. A study from the digestive tract of adult rats exposed to NP also found that the liver and kidney may be the primary target organs [32]. Hepatocyte culture in vitro was reported to be a simple and rapid way in vitro toxicology experimental system and a good way to study toxicology. NCTC Clone 1469 cell line provides an ideal 


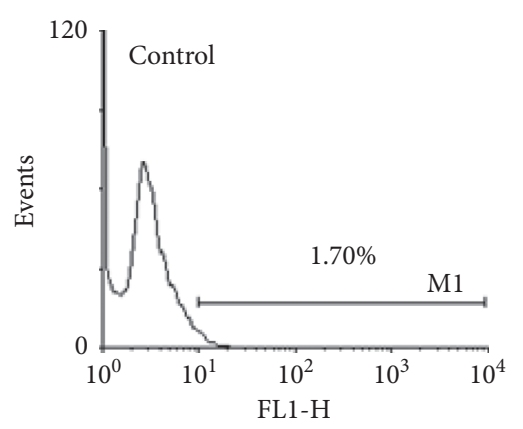

A

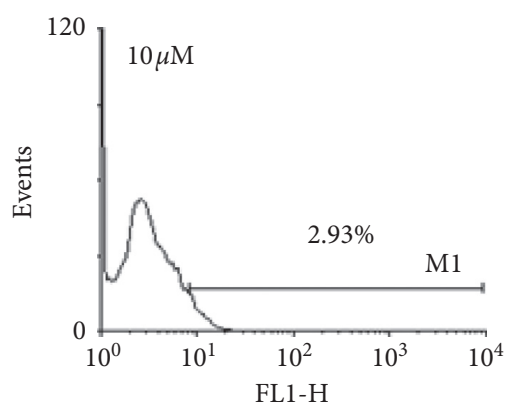

C

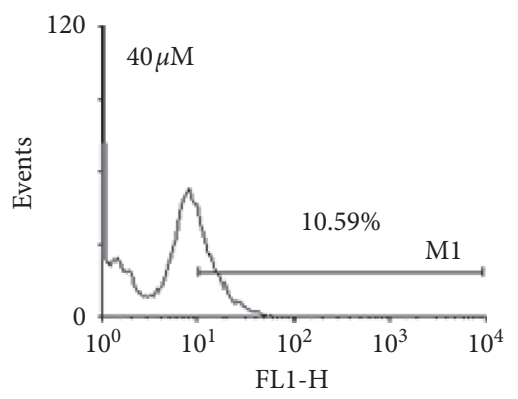

E

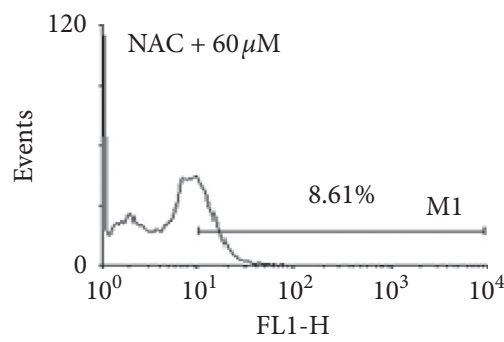

G

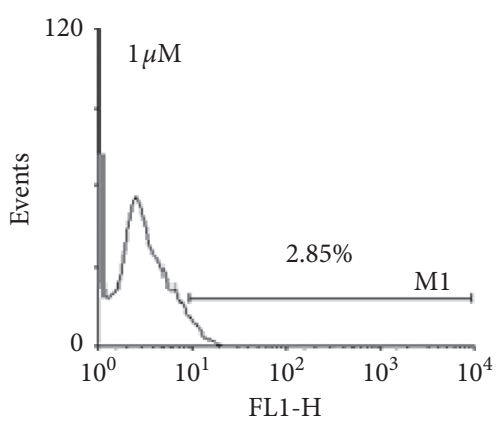

B

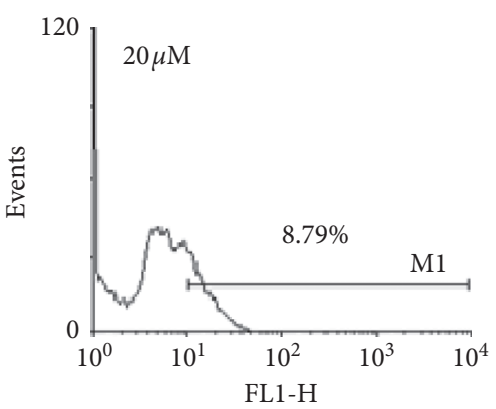

D

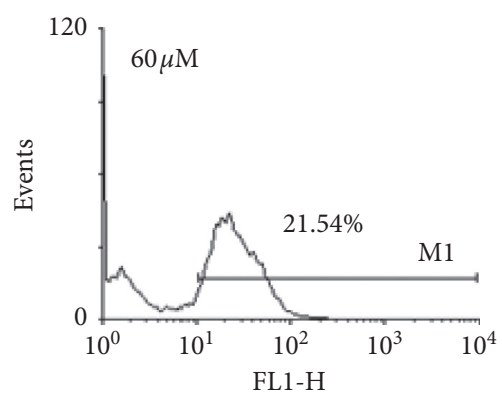

F

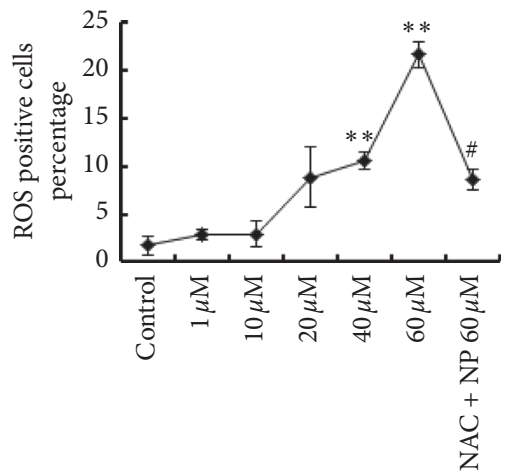

$\mathrm{H}$

(a)

Figure 2: Continued. 


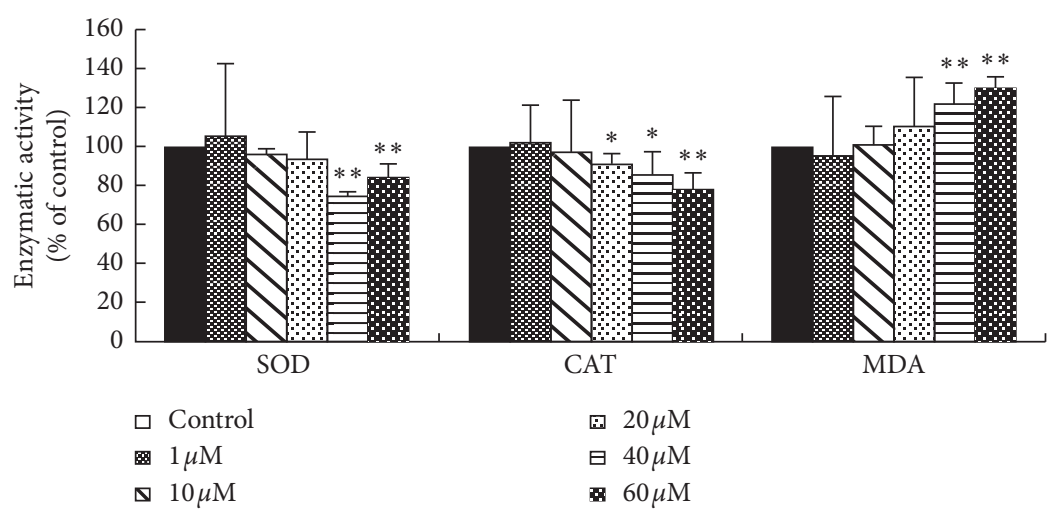

(b)

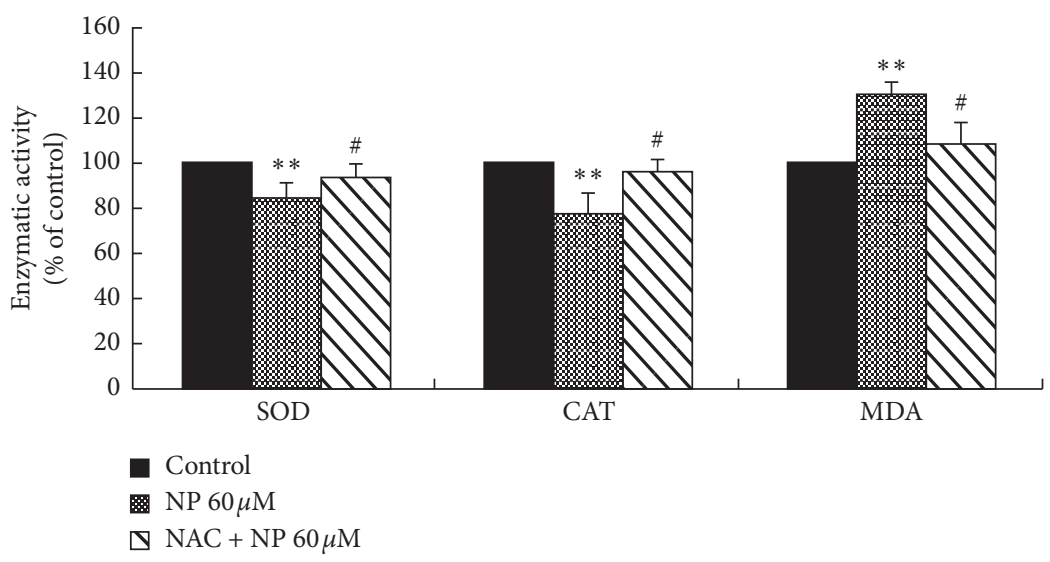

(c)

FIGURe 2: NP induced oxidative stress in NCTC Clone 1469 cells. (a) Intracellular ROS levels detected in cells. After exposure to NP for $12 \mathrm{~h}$, NCTC Clone 1469 were collected for DCFH-DA staining followed by flow cytometry analysis. (A-G) Flow cytometric plots. (H) Flow cytometric analysis result. (b) Effect of NP on intracellular SOD activity, CAT activity, and MDA content in NCTC Clone 1469. SOD activity, CAT activity, and MDA content are expressed as \% of control. (c) NAC weakened NP-induced alteration of SOD activity, CAT activity, and MDA content. Results are presented as mean \pm SD with triplicate measurement. ${ }^{*} P<0.05,{ }^{* *} P<0.01$ versus the control group; ${ }^{\#} P<0.05$ versus $60 \mu \mathrm{M}$ NP group.

system for the in vitro analysis of function and responsiveness to biochemical/hormonal factors of this particular cell type. Estrogen receptors were expressed in NCTC Clone 1469 , suggesting that this cell line could be useful for examining the relationship between liver injury and estrogenic actions. Now NCTC Clone 1469 cells were widely used in the research field about the effects of chemicals even alkylphenol on normal hepatocyte [33-35]. Thus, we cultured the NCTC Clone 1469 in vitro to investigate the underlying mechanisms of NP hepatotoxicity in the current study.

In the present study, we found that NP downregulated the viability of NCTC Clone 1469 in high concentration with $12 \mathrm{~h}$ incubation and shrunken cells revealed in microscopic observation, which indicated that NP showed stress or damage to NCTC Clone 1469. The amounts of LDH, ALT, and AST leakage in the supernatant were sensitive indicators to evaluate liver cell damage. $\mathrm{LDH}$ can catalyze the interconversion of lactic acid and pyruvic and regulate the body's normal physiological activity. LDH cannot get through the cell membrane under normal circumstances. However, when cells are damaged or poisoned, membrane permeability increases and $\mathrm{LDH}$ is released into the medium [36]. ALT is mainly present in the cytoplasm of liver cells, and its activity could significantly elevate when the cell membrane permeability changes in cell injury. AST is mainly located in the mitochondria and is released to the medium when the mitochondria are seriously damaged. NP enhanced the leakage of LDH, ALT, and AST activities in NCTC Clone 1469 , suggesting that NP at high concentrations strongly injured the cells, destructed the liver cell growth microenvironment, and caused an increase in membrane permeability.

Environmental contaminants can undergo redox cycling during the process of metabolism in organisms and produce large quantities of ROS. Oxidative stress induced by excess ROS can produce a series of toxic effects [37-39]. Previous studies have shown that NP increased intracellular ROS, regulated cell cycle, inhibited cell proliferation, and even led to cell death $[40,41]$. Oxidative stress is caused not only by excessive intracellular ROS but also by the decrease of intracellular antioxidants. MDA is a product of lipid peroxidation reaction; its content often reflects the extent of lipid 


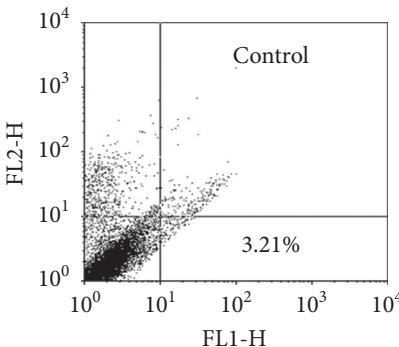

A

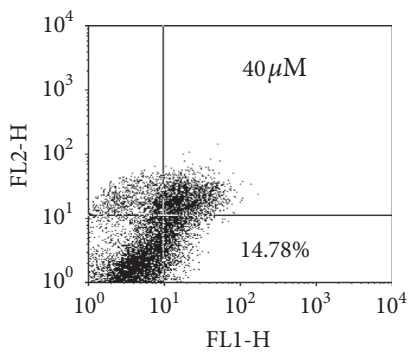

E

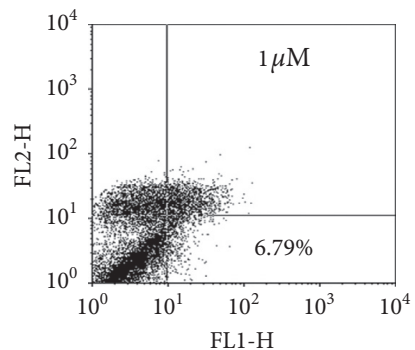

B

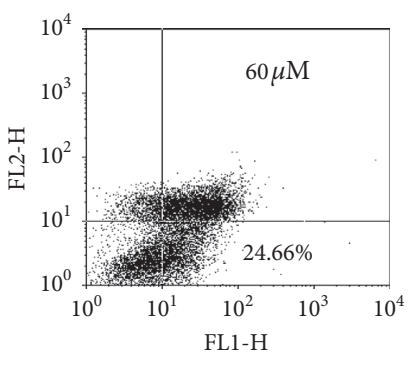

F

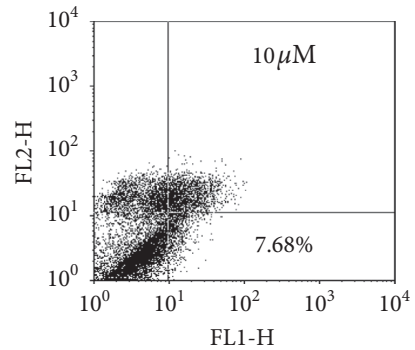

C

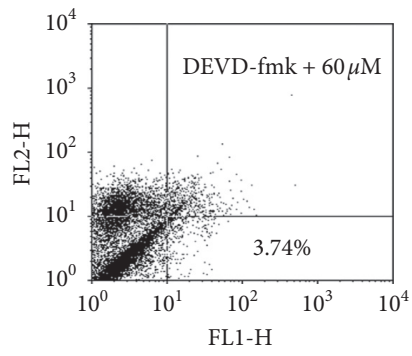

G

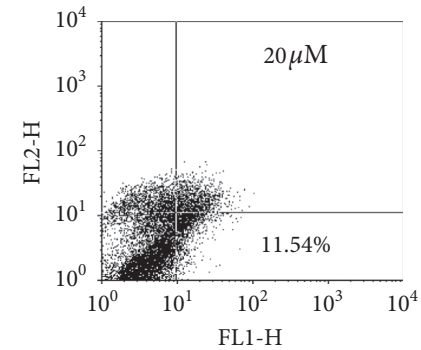

D

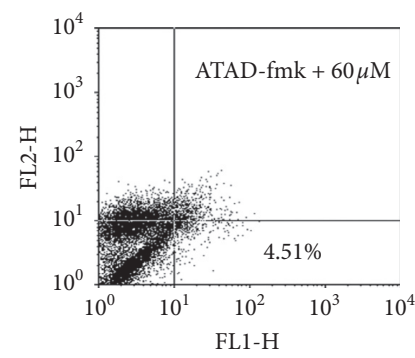

$\mathrm{H}$

(a)

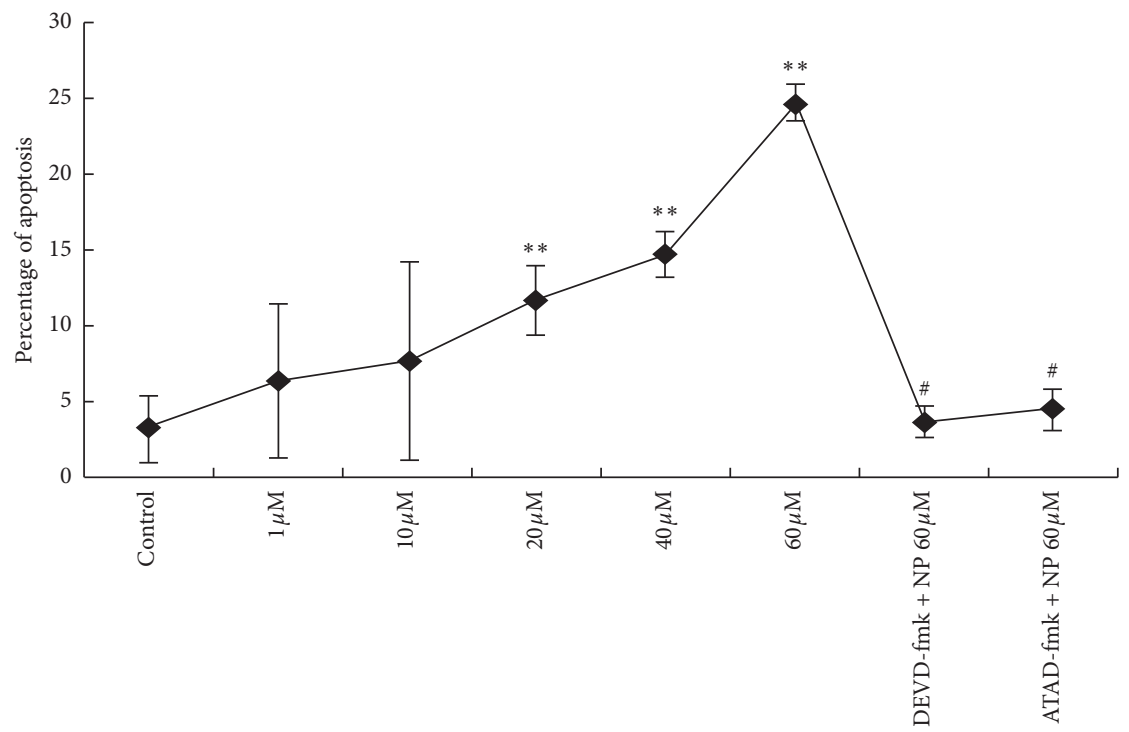

(b)

Figure 3: NP induced apoptosis in NCTC Clone 1469 cells. After exposure to NP for $12 \mathrm{~h}$, NCTC Clone 1469 were collected for Annexin V-FITC and PI staining followed by flow cytometry analysis. (a) Flow cytometric plots. (b) Flow cytometric analysis result. Results are presented as mean \pm SD with triplicate measurement. ${ }^{* *} P<0.01$ versus the control group; ${ }^{\#} P<0.05$ versus $60 \mu \mathrm{M}$ NP group.

peroxidation in organisms and the degree of cell damage indirectly $[42,43]$. The level of intracellular SOD activity reflects the ability of scavenging free radicals in the body indirectly, and CAT is a receiver of $\mathrm{H}_{2} \mathrm{O}_{2}$ generated within cells, an important material for antioxidative defense in different regions inside cells [44]. In this study, we found that NP induced oxidative stress in NCTC Clone 1469, as evidenced by the increase of intracellular ROS level and MDA content and the decrease of intracellular SOD and CAT activities in NP challenged cells. NP mediated oxidative stress in NCTC Clone 1469 could potentially contribute to cellular damage induced by NP.
NAC is a typical antioxidant widely used for inhibiting oxidative stress [45]. In order to explore the relationship between oxidative stress and the toxic effects of NP on liver cells, NAC was used to investigate whether it could attenuate NP-induced damage in NCTC Clone 1469. NAC pretreatment significantly increased the activity of SOD or CAT and dramatically decreased MDA content, indicating that NAC as an antioxidant can prevent cells from damage through reducing the extent of intracellular oxidative stress caused by NP treatment. Additionally, NAC significantly blocked NPinduced LDH, ALT, and AST activities upregulation in cells, indicating that antioxidants may reduce the toxic effects of 


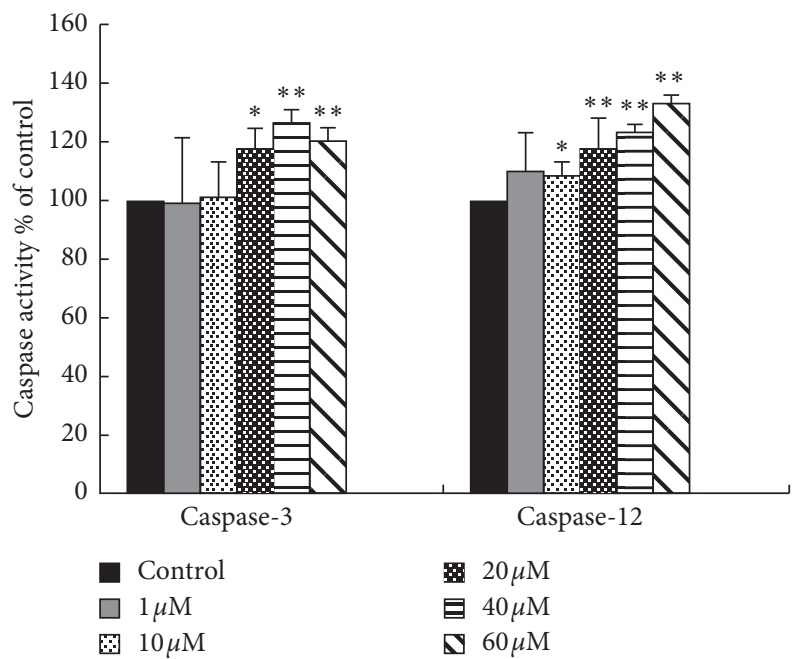

FIGURE 4: Effect of NP on the activities of caspases-3 and caspase-12. Results are presented as mean \pm SD with triplicate measurement. ${ }^{*} P<0.05,{ }^{* *} P<0.01$ versus control group.

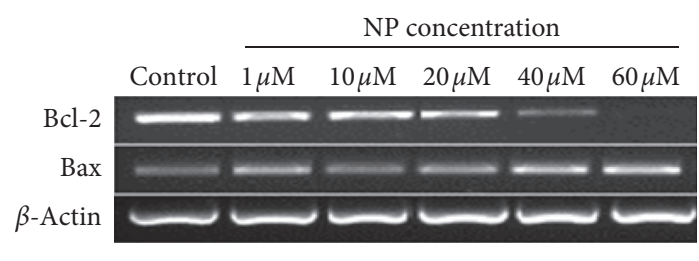

(a)

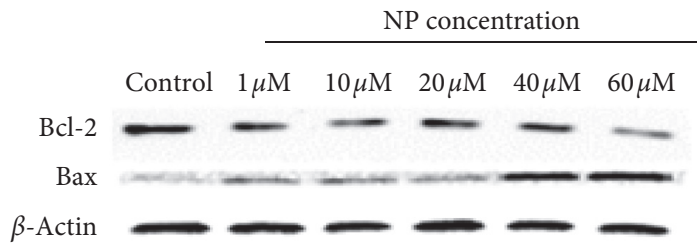

(c)

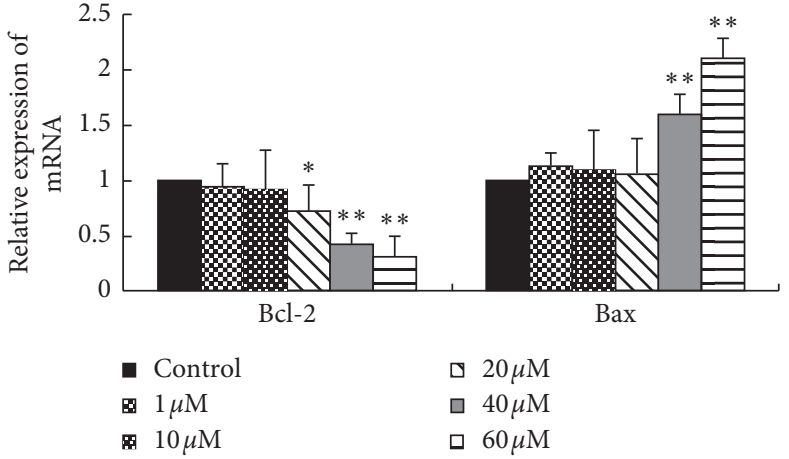

(b)

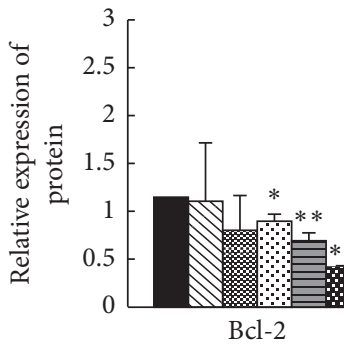

- Control

$\otimes 1 \mu \mathrm{M}$

ه $10 \mu \mathrm{M}$

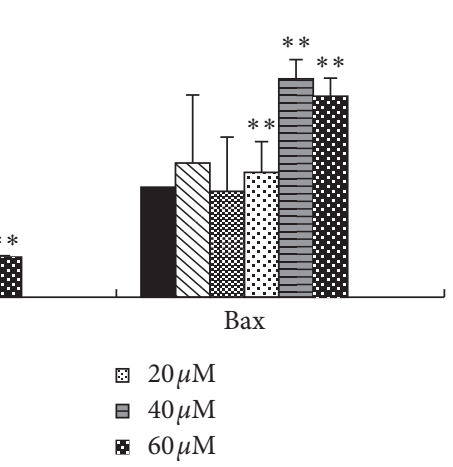

(d)

FiguRe 5: Protein and mRNA expression of Bax and Bal-2. (a) RT-PCR was performed for target genes and $\beta$-actin. (b) The histogram represents the quantification of Bax and Bcl-2 mRNA levels (levels of control cells/ $\beta$-actin defined as 1). (c) Western blot was performed for the target protein and $\beta$-actin. (d) The histogram represents the quantification of Bax and Bcl- 2 protein levels (levels of control cells/ $\beta$-actin defined as 1). Results are presented as mean $\pm \mathrm{SD}$ with triplicate measurement. ${ }^{*} P<0.05,{ }^{* *} P<0.01$ versus the control group.

NP on liver cells, and oxidative stress may be one potential factor of cell toxicity caused by NP.

Apoptosis has a very important role in the maintenance of tissues, normal morphology, and function of the organ, and body homeostasis was maintained by cell proliferation and apoptosis mutually. Much research has indicated that apoptosis is one of the reasons for toxic effects by environmental interference. It has been reported that the toxic effects of NP may be related to apoptosis in cells while there is still a lack of reports about apoptosis of mammalian liver caused by NP. Many studies have shown that excess of ROS can promote apoptosis [46]. Intracellular ROS generation 


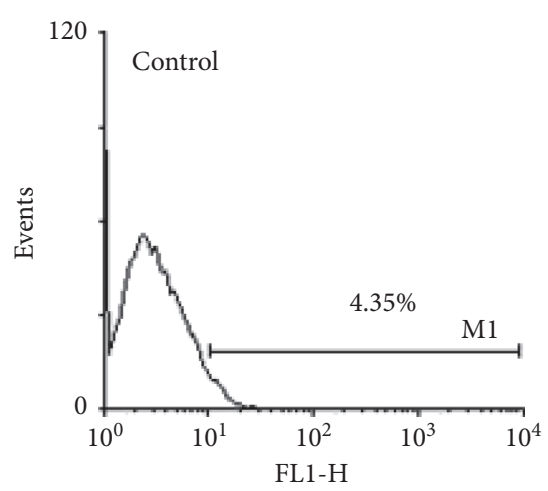

A

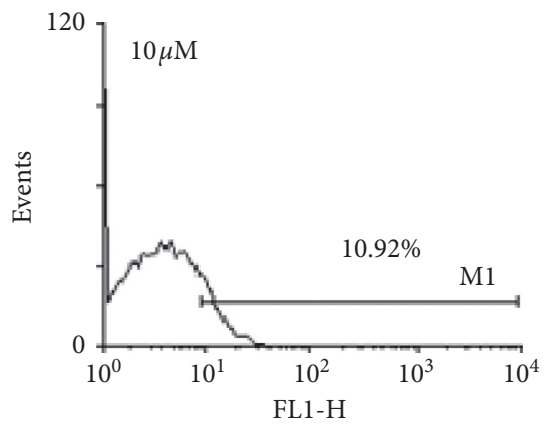

C

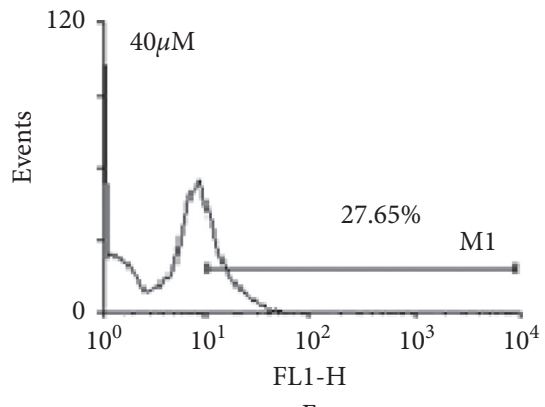

E

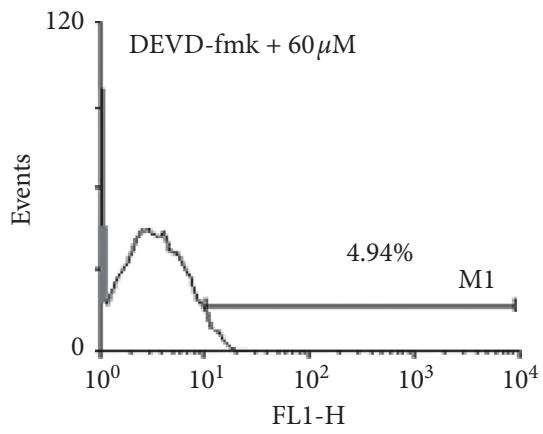

G

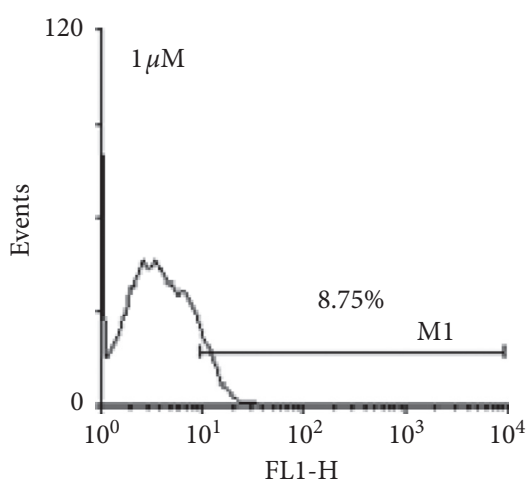

B

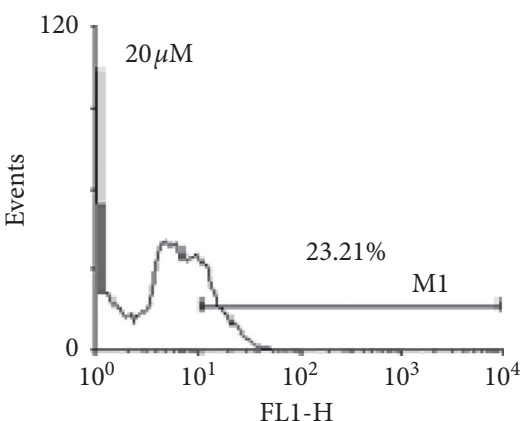

D

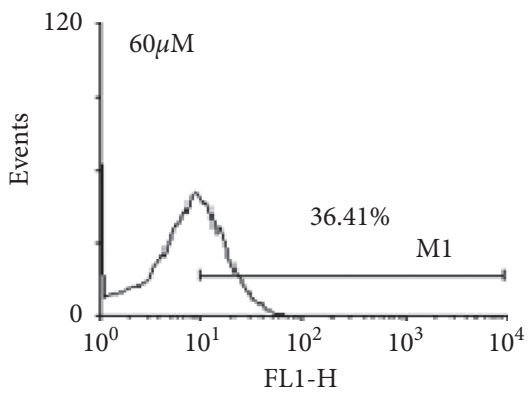

F

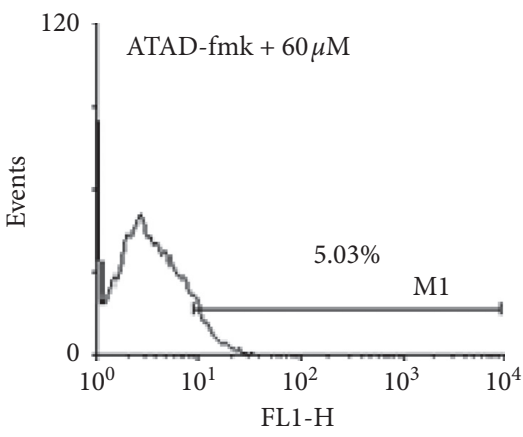

$\mathrm{H}$

(a)

Figure 6: Continued. 


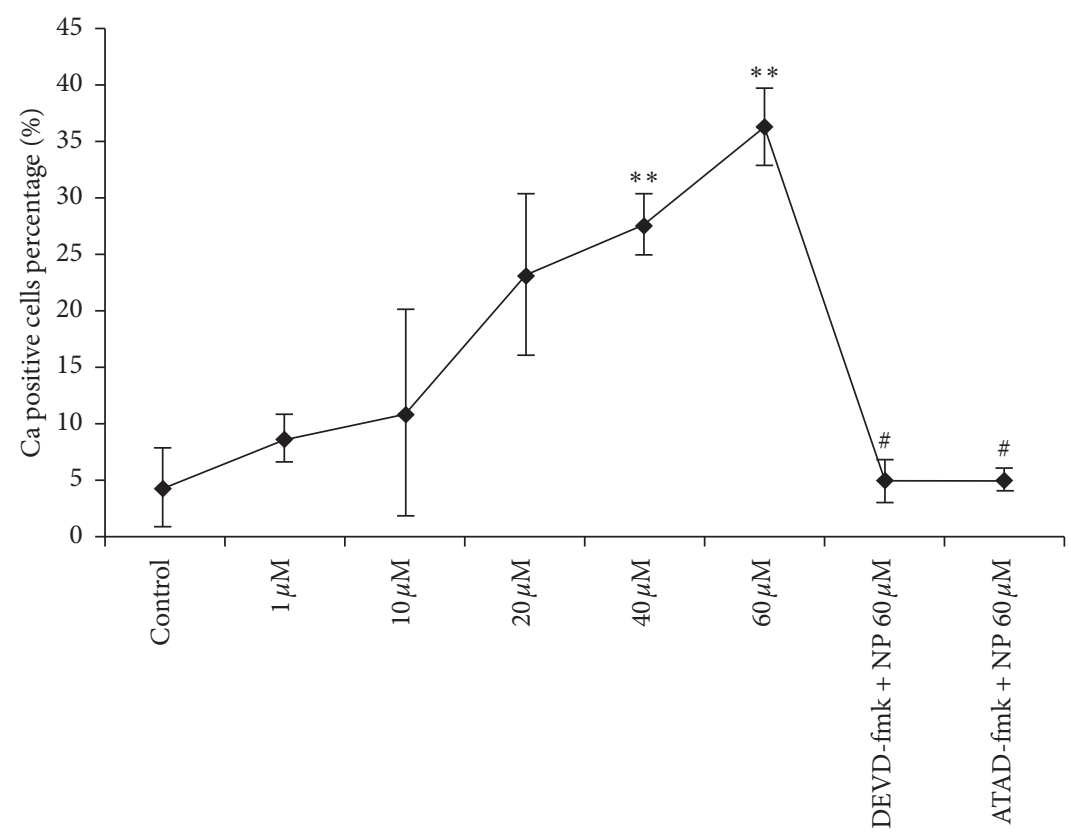

(b)

Figure 6: NP-induced $\mathrm{Ca}^{2+}$ release in NCTC Clone 1469 cells. The appearance of $\mathrm{Ca}^{2+}$ release was detected by flow cytometry using Fluo-3/ AM fluorescent probe. For each sample, 20,000 cells were analyzed. (a) Flow cytometric plots. (b) Flow cytometric analysis result. Results are presented as mean \pm SD with triplicate measurement. ${ }^{*} P<0.05,{ }^{* *} P<0.01$ versus the control group, ${ }^{\#} P<0.05$ versus $60 \mu \mathrm{M}$ NP group.
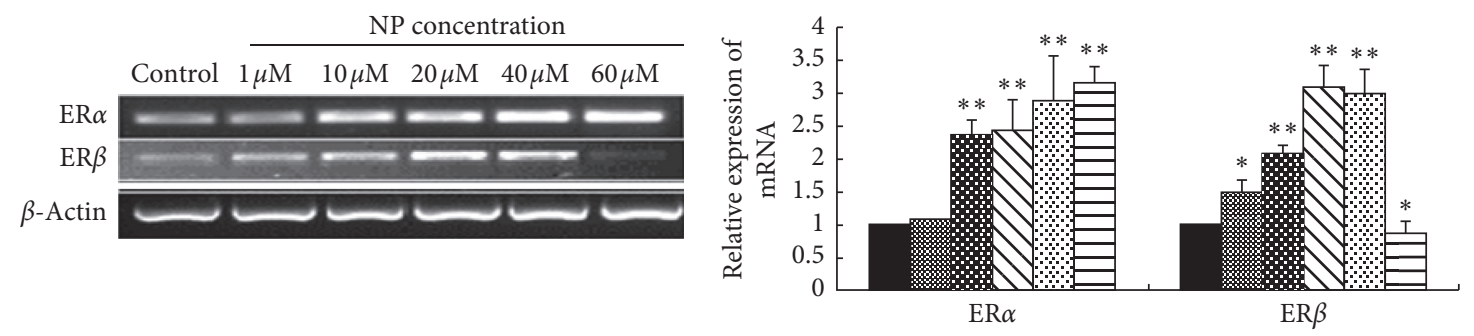

- Control

目 $1 \mu \mathrm{M}$

$10 \mu \mathrm{M}$

(a)

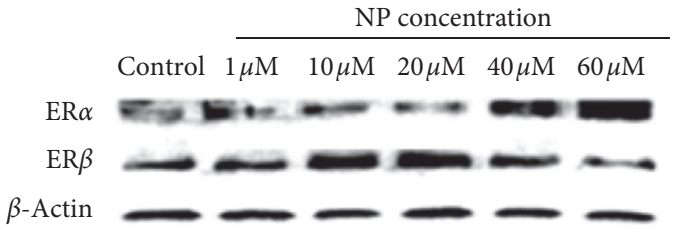

(c)

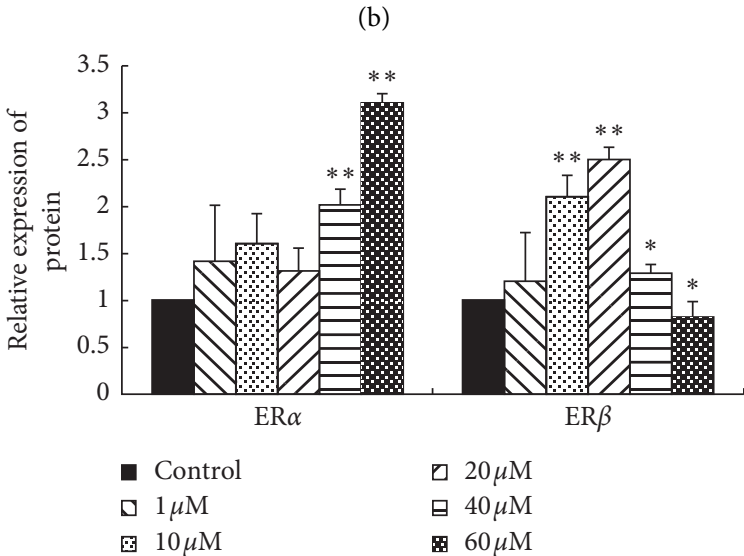

(d)

Figure 7: Protein and mRNA expression of ER- $\alpha$ and ER- $\beta$. (a) RT-PCR was performed for target genes and $\beta$-actin. (b) The histogram represents the quantification of ER- $\alpha$ and ER- $\beta$ mRNA levels (levels of control cells/ $\beta$-actin defined as 1 ). (c) Western blot was performed for the target protein and $\beta$-actin. (d) The histogram represents the quantification of ER- $\alpha$ and ER- $\beta$ protein levels (levels of control cells/ $\beta$-actin defined as 1). Results are presented as mean \pm SD with triplicate measurement. ${ }^{*} P<0.05,{ }^{* *} P<0.01$ versus the control group. 


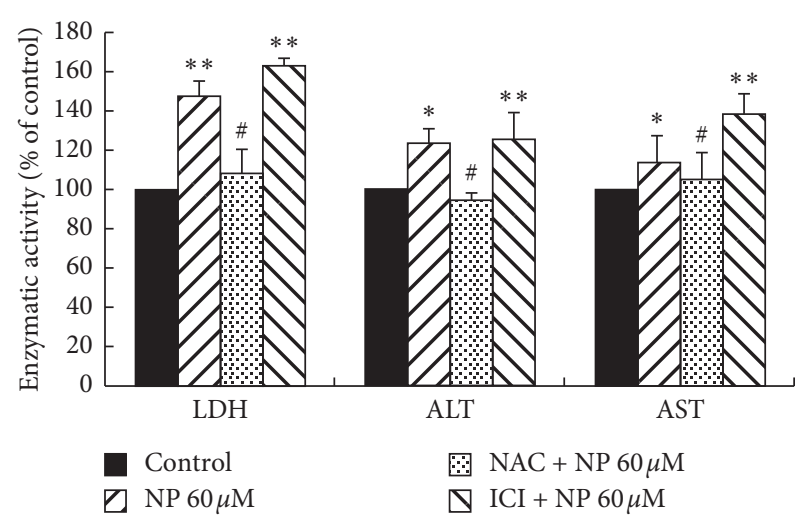

Figure 8: Effects of NAC and ICI 182,780 on NP-induced alteration of LDH, ALT, and AST activities. Results are presented as mean $\pm \mathrm{SD}$ with triplicate measurement. ${ }^{*} P<0.05,{ }^{* *} P<0.01$ versus the control group, ${ }^{\#} P<0.05$ versus $60 \mu \mathrm{M}$ NP group.

was observed in NP challenged NCTC Clone 1469; thus, apoptosis was detected to provide further insights in NPinduced hepatotoxicity. The process of apoptosis is regulated by a series of related genes, including Bcl-2 family. Bcl-2 is the first gene to be confirmed to inhibit apoptosis, mainly in the outer mitochondrial membrane and nuclear membrane, and is able to prevent the release of proapoptotic factors such as cytochrome $\mathrm{c}$, maintain the stability of intracellular $\mathrm{Ca}^{2+}$, decrease accumulation of free radicals, and finally inhibit apoptosis. Bax, a homologous protein of Bcl-2, can cause changes in mitochondrial permeability and release of cytochrome $c$, starting apoptosis reaction associated with Caspase. NP promoted the apoptosis of NCTC Clone 1469, accompanied by decrease of Bcl-2 and increase of Bax and intracellular free $\mathrm{Ca}^{2+}$. Caspase is the core of apoptosis, caspase- 3 called apoptosis executor is the final effect factor in apoptotic protein cascades reaction, and caspase- 12 is a major regulator of apoptosis as well. In this study, NP at high concentrations significantly increased caspase- 3 and caspase-12 activity. Meanwhile, the cell apoptosis level decreased remarkably because of the blocking of caspase- 3 and caspase-12. These results revealed that NP could result in apoptosis through upregulating expression of Bax, downregulating $\mathrm{Bcl}-2$, and activation of caspase- 12 and caspase- 3 . Therefore, our results suggested that NP could produce toxic effects on NCTC Clone 1469, but the exact intracellular transduction pathways were still undefined. Thus, additional studies are required to further elucidate on the detailed mechanisms by which NP causes toxic effects.

ICI 182,780 is a kind of ER antagonists that can compete with estrogens for receptor binding. NP has a similar chemical structure to $17 \beta$-estradiol (E2), so it could inhibit competitively the binding of E2 and ER in the target organs. After NP and ER forming a ligand, they bind the response element in DNA binding domain and then induce or inhibit transcription of target genes, starting a series of estrogen-dependent physiological and biochemical processes [47]. ER has two subtypes: ER- $\alpha$ and ER- $\beta$; both can be expressed at different levels in normal liver tissue [48]. NP altered the expression of ER- $\alpha$ and ER- $\beta$ in NCTC Clone 1469. However, we found that ICI 182,780 did not reduce LDH, ALT, and AST activities in the supernatant, suggesting that NP exerted potential estrogenic effect in liver cells, while the toxic effects of NP on the liver cells showed no direct relationship with the ER receptor.

In summary, the current study implied that NP showed cytotoxicity to NCTC Clone 1469 cells. Oxidative stress and apoptosis were involved in NP-induced cytotoxicity while this may not be mediated by estrogenic effect directly.

\section{Conclusion}

We found that NP exhibited toxic effects on NCTC Clone 1469 cells, including morphological change, the decrease of cell viability, and the leakage of intracellular enzymes. NAC weakened the effects of NP on NCTC Clone 1469 cells; we speculated that oxidative stress may be one of the mechanisms contributing to NP toxicity. Furthermore, NP induced apoptosis in NCTC Clone 1469, accompanied by decreasing expression of Bcl-2, increasing expression of Bax, upregulating intracellular $\mathrm{Ca}^{2+}$ level, and activating caspase-3/12 activities. Additionally, the results showed that NP affected the expression of ER- $\alpha$ and ER- $\beta$ in NCTC Clone 1469. However, ICI 182,780 have no effects on NP-induced damage in NCTC Clone 1469. We concluded that NP induced damage to NCTC Clone 1469 cells via mediated oxidative stress and apoptosis in cells, which may not be related to the estrogenic effect of NP.

\section{Abbreviations}

ALT: Alanine aminotransferase

AST: Aspartate transaminase

CAT: $\quad$ Catalase

DCF: $\quad 2^{\prime}-7^{\prime}$-Dichlorofluorescein

DCFH- 5(6)-Carboxy-2 $2^{\prime}-7^{\prime}$-dichlorofluorescein diacetate

DA:

DMEM- Dulbecco's modified Eagle's medium-high

$\mathrm{H}: \quad$ glucose medium

EDCs: Endocrine-disrupting compounds

ER- $\alpha$ : $\quad$ Estrogen receptor $\alpha$

ER- $\beta$ : $\quad$ Estrogen receptor $\beta$

HRP: $\quad$ Horseradish peroxidase

LDH: Lactate dehydrogenase

MDA: Maleic dialdehyde

MTT: $\quad 3-[4,5-D i m e t h y l t h i a z o l-2 y l]-2,5-d i p h e n y l$ tetrazolium bromide

NAC: N-acetyl-L-cysteine

NP: Nonylphenol

NPEOs: Nonylphenol polyethoxylate

PBS: $\quad$ Phosphate-buffered saline

ROS: $\quad$ Reactive oxygen species

RT-PCR: Reverse transcription-polymerase chain reaction SOD: $\quad$ Superoxide dismutase.

\section{Data Availability}

The data used to support the findings of this study are available from the corresponding author upon request. 


\section{Conflicts of Interest}

The authors declare that there are no conflicts of interest.

\section{Acknowledgments}

This study was supported by the National Natural Science Foundation of China (81803193), Institute of Science and Technology Innovation, DGUT (no. KCYCXPT2017007), Natural Science Foundation of Guangdong Province, China (no. 2018A030310033), the Open Project Program of State Key Laboratory of Food Science and Technology, Nanchang University (no. SKLF-KF-201801), General Social Science projects in Dongguan (no. 20185071401508), and research start-up funds of DGUT (GC300502-33).

\section{References}

[1] M. Hawrelak, E. Bennett, and C. Metcalfe, "The environmental fate of the primary degradation products of alkylphenol ethoxylate surfactants in recycled paper sludge," Chemosphere, vol. 39, no. 5, pp. 745-752, 1999.

[2] E. C. Bonefeldjørgensen, M. Long, M. V. Hofmeister, and A. M. Vinggaard, "Endocrine-disrupting potential of bisphenol A, bisphenol A dimethacrylate, 4-n-nonylphenol, and 4-n-octylphenol in vitro: new data and a brief review," Environmental Health Perspectives, vol. 115, pp. 69-76, 2007.

[3] J. R. Cheng, K. Wang, J. Yu, Z. X. Yu, X. B. Yu, and Z. Z. Zhang, "Distribution and fate modeling of 4-nonylphenol, 4-t-octylphenol, and bisphenol A in the Yong river of China," Chemosphere, vol. 195, pp. 594-605, 2017.

[4] Z. Noorimotlagh, N. J. Haghighi, M. Ahmadimoghadam, and F. Rahim, "An updated systematic review on the possible effect of nonylphenol on male fertility," Environmental Science and Pollution Research International, vol. 24, pp. 1-17, 2016.

[5] C. L. G. Rivero, A. C. Barbosa, M. F. N. Ferreira, J. G. Dorea, and C. K. Grisolia, "Evaluation of genotoxicity and effects on reproduction of nonylphenol in Oreochromis niloticus (pisces: cichlidae)," Ecotoxicology, vol. 17, no. 8, pp. 732-737, 2008.

[6] P. D. Voogt, O. Kwast, R. Hendriks, and N. Jonkers, "Alkylphenol ethoxylates and their degradation products in abiotic and biological samples from the environment," Analusis, vol. 28, pp. 776-782, 2000.

[7] N. G. Coldham, S. Sivapathasundaram, M. Dave et al., "Biotransformation, tissue distribution, and persistence of 4nonylphenol residues in juvenile rainbow trout (Oncorhynchus mykiss)," Drug Metabolism and Disposition: The Biological Fate of Chemicals, vol. 26, no. 4, pp. 347-354, 1998.

[8] G.-G. Ying, B. Williams, and R. Kookana, "Environmental fate of alkylphenols and alkylphenol ethoxylates-a review," Environment International, vol. 28, pp. 215-226, 2002.

[9] K. Inoue, S. Kondo, Y. Yoshie et al., "Migration of 4-nonylphenol from polyvinyl chloride food packaging films into food simulants and foods," Food Additives and Contaminants, vol. 18, no. 2, pp. 157-164, 2001.

[10] Y. Kawamura, Y. Ogawa, and M. Mutsuga, "Migration of nonylphenol and plasticizers from polyvinyl chloride stretch film into food simulants, rapeseed oil, and foods," Food Science \& Nutrition, vol. 5, no. 3, pp. 390-398, 2017.
[11] C. Cox, "Nonyl phenol and related chemicals," Journal of Pesticide Reform: A Publication of the Northwest Coalition for Alternatives to Pesticides, vol. 16, pp. 15-20, 2003.

[12] X. Jie, W. Yang, Y. Jie et al., "Immune effects of nonylphenol on offspring of rats exposed during pregnancy," Human and Ecological Risk Assessment: An International Journal, vol. 16, no. 2, pp. 444-452, 2010.

[13] S. S. Kumaran, C. Kavitha, M. Ramesh, and T. Grummt, "Toxicity studies of nonylphenol and octylphenol: hormonal, hematological and biochemical effects in Clarias gariepinus," Journal of Applied Toxicology, vol. 31, pp. 752-761, 2011.

[14] Z. Mao, Y.-L. Zheng, and Y.-Q. Zhang, "Behavioral impairment and oxidative damage induced by chronic application of nonylphenol," International Journal of Molecular Sciences, vol. 12, no. 1, pp. 114-127, 2010.

[15] Q.-N. Korach, W.-X. Cao, R. Xu, L. Lu, Q. Xu, and X.-B. Wang, "Chronic low-dose exposure of nonylphenol alters energy homeostasis in the reproductive system of female rats," Toxicology and Applied Pharmacology, vol. 348, no. 1, pp. 67-75, 2018.

[16] D. R. Doerge, N. C. Twaddle, M. I. Churchwell, H. C. Chang, R. R. Newbold, and K. B. Delclos, "Mass spectrometric determination of $\mathrm{p}$-nonylphenol metabolism and disposition following oral administration to Sprague-Dawley rats," Reproductive Toxicology, vol. 16, no. 1, pp. 45-56, 2002.

[17] S. Probst-Cousin, C. H. Rickert, K. W. Schmid, and F. Gullota, "Cell death mechanisms in multiple system atrophy," Journal of Neuropathology and Experimental Neurology, vol. 57, no. 9, pp. 814-821, 1998.

[18] V. C. George and H. P. V. Rupasinghe, "DNA damaging and apoptotic potentials of bisphenol $\mathrm{A}$ and bisphenol $\mathrm{S}$ in human bronchial epithelial cells," Environmental Toxicology and Pharmacology, vol. 60, pp. 52-57, 2018.

[19] J. D. Robertson and S. Orrenius, "Role of mitochondria in toxic cell death," Toxicology, vol. 181-182, pp. 491-496, 2002.

[20] M. Aoki, M. Kurasaki, T. Saito et al., "Nonylphenol enhances apoptosis induced by serum deprivation in PC12 cells," Life Sciences, vol. 74, no. 18, pp. 2301-2312, 2004.

[21] G. Yao, Y. Hu, J. Liang, and Y. Hou, "Nonylphenol-induced thymocyte apoptosis is related to Fas/FasL pathway," Life Sciences, vol. 77, no. 26, pp. 3306-3320, 2005.

[22] J. Yuan and B. A. Yankner, "Apoptosis in the nervous system," Nature, vol. 407, no. 6805, pp. 802-809, 2000.

[23] X. Park, S. Nie, D. Huang, and M. Xie, "Mitogen-activated protein kinase and Akt pathways are involved in 4-n-nonyphenol induced apoptosis in mouse Sertoli TM4 cells," Environmental Toxicology and Pharmacology, vol. 39, no. 2, pp. 815-824, 2015.

[24] H. Ding and Z. Wen, "Overexpression of C-sis inhibits $\mathrm{H}_{2} \mathrm{O}_{2}$ induced buffalo rat liver cell apoptosis in vitro and alleviates liver injury in a rat model of fulminant hepatic failure," International Journal of Molecular Medicine, vol. 42, no. 2, pp. 873-882, 2018.

[25] A. Mahmoudi, F. Hadrich, I. Feki et al., "Oleuropein and hydroxytyrosol rich extracts from olive leaves attenuate liver injury and lipid metabolism disturbance in bisphenol A-treated rats," Food \& Function, vol. 10, p. 1039, 2018.

[26] D. D. Rio, A. J. Stewart, and N. Pellegrini, "A review of recent studies on malondialdehyde as toxic molecule and biological marker of oxidative stress," Nutrition, Metabolism \& Cardiovascular Diseases, vol. 15, pp. 316-328, 2005.

[27] T. Y. Forbes-Hernández, F. Giampieri, M. Gasparrini et al., "The effects of bioactive compounds from plant foods on 
mitochondrial function: a focus on apoptotic mechanisms," Food and Chemical Toxicology, vol. 68, pp. 154-182, 2014.

[28] A. Aouacheria, S. Baghdiguian, H. M. Lamb, J. D. Huska, F. J. Pineda, and J. M. Hardwick, "Connecting mitochondrial dynamics and life-or-death events via Bcl-2 family proteins," Neurochemistry International, vol. 109, pp. 141-161, 2017.

[29] K. J. Campbell and S. W. G. Tait, "Targeting BCL-2 regulated apoptosis in cancer," Open Biology, vol. 8, no. 5, Article ID 180002, 2018.

[30] S. J. Kwack, O. Kwon, H. S. Kim et al., "Comparative evaluation of alkylphenolic compounds on estrogenic activity in vitro and in vivo," Journal of Toxicology and Environmental Health, Part A, vol. 65, no. 5-6, pp. 419-431, 2002.

[31] S. Cooper, J. R. Latendresse, D. R. Doerge, N. C. Twaddle, $\mathrm{X}$. Fu, and K. B. Delclos, "Dietary modulation of p-nonylphenol-induced polycystic kidneys in male Sprague-Dawley rats," Toxicological Sciences, vol. 91, no. 2, pp. 631-642, 2006.

[32] X. Jie, W. Yang, Y. Jie et al., "Toxic effect of gestational exposure to nonylphenol on F1 male rats," Birth Defects Research Part B: Developmental and Reproductive Toxicology, vol. 89, no. 5, pp. 418-428, 2010.

[33] J. Asahi, H. Kamo, R. Baba et al., "Bisphenol A induces endoplasmic reticulum stress-associated apoptosis in mouse non-parenchymal hepatocytes," Life Sciences, vol. 87, no. 1314, pp. 431-438, 2010.

[34] T. Wu, M. Shen, S. Liu, Q. Yu, Y. Chen, and J. Xie, “Ameliorative effect of Cyclocarya paliurus polysaccharides against carbon tetrachloride induced oxidative stress in liver and kidney of mice," Food and Chemical Toxicology, vol. 135, Article ID 111014, 2020.

[35] J. Xie, H. Ye, M. Du, Q. Yu, Y. Chen, and M. Shen, "Mung bean protein hydrolysates protect mouse liver cell line NCTC1469 cell from hydrogen peroxide-induced cell injury," Foods, vol. 9, no. 1, p. 14, 2019.

[36] W. L. Seddon and C. Ladd Prosser, "Non-enzymatic isolation and culture of channel catfish hepatocytes," Comparative Biochemistry and Physiology Part A: Molecular \& Integrative Physiology, vol. 123, no. 1, pp. 9-15, 1999.

[37] T. Feng, W. Zheng, W. Hong, and G. Peng, "Effect of benzo(a) pyrene on antioxidant enzyme activities in Boleophthalmus pectinirostris liver," The Journal of Applied Ecology, vol. 12, pp. 422-424, 2001.

[38] R. T. D. Giulio, P. C. Washburn, R. J. Wenning, G. W. Winston, and C. S. Jewell, "Biochemical responses in aquatic animals: a review of determinants of oxidative stress," Environmental Toxicology and Chemistry, vol. 8, pp. 11031123, 2010.

[39] Y. Gong and X. D. Han, "Nonylphenol-induced oxidative stress and cytotoxicity in testicular Sertoli cells," Reproductive Toxicology, vol. 22, no. 4, pp. 623-630, 2006.

[40] Y. Qi, Y. Zhang, Y. Liu, and W. Zhang, "Nonylphenol decreases viability and arrests cell cycle via reactive oxygen species in Raji cells," Experimental and Toxicologic Pathology, vol. 65, no. 1-2, pp. 69-72, 2013.

[41] O. Yasuji, E. F. Sato, H. O. Kiyoka, and I. Masayasu, "Enhancing effect of the endocrine disruptor para-nonylphenol on the generation of reactive oxygen species in human blood neutrophils," Environmental Health Perspectives, vol. 112, pp. 553-556, 2004.

[42] F. Kucukdurmaz, E. Efe, A. Çelik, H. Dagli, M. Kılınc, and S. Resim, "Evaluation of serum prolidase activity and oxidative stress markers in men with BPH and prostate cancer," BMC Urology, vol. 17, pp. 116-121, 2017.
[43] C. Uchendu, S. F. Ambali, J. O. Ayo, and K. A. N. Esievo, "Chronic co-exposure to chlorpyrifos and deltamethrin pesticides induces alterations in serum lipids and oxidative stress in Wistar rats: mitigating role of alpha-lipoic acid," Environmental Science and Pollution Research, vol. 25, no. 20, pp. 19605-19611, 2018.

[44] V. Matozzo, L. Ballarin, and M. G. Marin, "Exposure of the clam tapes philippinarum to 4-nonylphenol: changes in antioxidant enzyme activities and re-burrowing capability," Marine Pollution Bulletin, vol. 48, no. 5-6, pp. 563-571, 2004.

[45] F. A. Ansari, A. A. Khan, and R. Mahmood, "Protective effect of carnosine and $\mathrm{N}$-acetylcysteine against sodium nitriteinduced oxidative stress and DNA damage in rat intestine," Environmental Science and Pollution Research, vol. 25, no. 20, pp. 19380-19392, 2018.

[46] N. J. Holbrook and S. Ikeyama, "Age-related decline in cellular response to oxidative stress: links to growth factor signaling pathways with common defects," Biochemical Pharmacology, vol. 64, no. 5-6, pp. 999-1005, 2002.

[47] G. Cakmak, I. Togan, and F. Severcan, "17 $\beta$-estradiol induced compositional, structural and functional changes in rainbow trout liver, revealed by FT-IR spectroscopy: a comparative study with nonylphenol," Aquatic Toxicology, vol. 77, no. 1, pp. 53-63, 2006.

[48] V. L. Davis, R. R. Newbold, J. F. Couse et al., "Expression of a dominant negative estrogen receptor alpha variant in transgenic mice accelerates uterine cancer induced by the potent estrogen diethylstilbestrol," Reproductive Toxicology, vol. 34, no. 4, pp. 512-521, 2012. 